\title{
Study on the Relationship between Liver Parasitic Infections and Serum Vitamin A and $\beta$-Carotene Status in Cattle
}

\author{
Sığırlarda Karaciğer Parazit Enfeksiyonları ile Serum A Vitamin ve $\beta$-Karoten Seviyeleri \\ Arasındaki İlişki
}

\author{
Ghader Jalilzadeh-Amin¹, Bijan Esmaeilnejad², Farhad Farhang-Pajuh² \\ 'Department of Clinical Sciences, Urmia University Faculty of Veterinary Medicine, Urmia, Iran \\ 2Department of Pathobiology, Urmia University Faculty of Veterinary Medicine, Urmia, Iran
}

Cite this article as: Jalilzadeh-Amin G, Esmaeilnejad B, Farhang-Pajuh F. Study on the Relationship between Liver Parasitic Infections and Serum Vitamin A and $\beta$-Carotene Status in Cattle. Türkiye Parazitol Derg 2017; 41: 198-203.

\section{ABSTRACT}

Objective: This study was conducted to evaluate the relationship between serum levels of vitamin $A$ and $\beta$-carotene in the liver of cattle. Methods: A total number of 150 samples were selected according to the type of parasitic infections of the liver after postmortem examination and confirmation. Parasitic lesions in the liver were subdivided into three major parasites, including Fasciola hepatica, Dicrocoelium dendriticum, and hydatid cysts. Fifty samples were obtained from cattle without any parasitic infection as a control group. Serum levels of vitamin A, $\beta$-carotene concentrations ( $\mu \mathrm{g} / \mathrm{dL}$ ), alanine aminotransferase (ALT), and aspartate aminotransferase (AST) activity were assayed. Results: Naturally infected cattle with D. dendriticum, F. hepatica and hydatid cyst showed lower vitamin A levels. Serum $\beta$-carotene levels were significantly decreased in all groups $(p<0.05)$. ALT and AST activities in animals with parasitic diseases were statistically higher than in control group $(p<0.01)$. A significant negative correlation was determined between the $\beta$-carotene, vitamin $A$ levels and enzyme activities of the liver in all the three types of liver infections $(p<0.001)$.

Conclusions: This study indicated that serum levels of vitamin $A$ and $\beta$-carotene decline was present in cattle with liver parasite infection and vitamin supplements should be supplied.

Keywords: Provitamin A, Parasitic hepatitis, D. dendriticum, F. hepatica, cyst hydatid

Received: 24.04.2017

Accepted: 09.10.2017

\section{ÖZ}

Amaç: Bu çalışma sığır karaciğerinde serum A vitamini ve $\beta$-karoten değerleri arasındaki ilişkiyi değerlendirmek için yapıldı.

Yöntemler: Postmortem inceleme ve konfirmasyon sonrasında karaciğer parazit enfeksiyonu türüne göre toplam 150 örneklem seçildi. Karaciğerdeki parazitik lezyonlar Fasciola hepatica, Dicrocoelium dendriticum ve hidatik kist olarak üç gruba ayrıldı. Kontrol grubu olarak herhangi bir parazit enfeksiyonu olmayan sığılardan 50 örnek alındı. A vitamini, $\beta$-karoten ( $\mu \mathrm{g} / \mathrm{dL}$ ), alanin aminotransferaz (ALT) ve aspartat aminotransferaz (AST) düzeyleri değerlendirildi.

Bulgular: D. dendriticum, F. hepatica ve hidatik kist olan doğal yollardan enfekte olmuş sığırlarda A vitamini seviyeleri daha düşüktü. Serum $\beta$-karoten düzeyleri tüm gruplarda anlamlı şekilde düşük bulundu $(p<0,05)$. Parazitik hastalığı olan hayvanlarda ALT ve AST aktiviteleri kontrol grubuna göre anlamlı derecede daha yüksekti $(p<0,01)$. Üç tip karaciğer enfeksiyonunun tümünde, $\beta$-karoten ve $A$ vitamini seviyeleri ile karaciğer enzim aktiviteleri arasında anlamlı bir negatif korelasyon saptandı $(p<0,001)$.

Sonuç: Bu çalışmanın bulgularına göre, karaciğer parazit enfeksiyonu olan sığırlarda düşük serum A vitamini ve $\beta$-karoten seviyeleri görülmüştür ve vitamin takviyeleri verilmelidir.

Anahtar sözcükler: Provitamin A, Parazitik hepatit, D. dendriticum, F. hepatica, hidatik kist

Geliş Tarihi: 24.04.2017

Kabul Tarihi: 09.10.2017

Address for Correspondence / Yazışma Adresi: Bijan Esmaeilnejad, E.mail: b_esmaeilnejad@yahoo.com DOI: $10.5152 /$ tpd.2017.5364

(C) Copyright 2017 Turkish Society for Parasitology - Available online at www.tparazitolderg.org

OCTelif hakkı 2017 Türkiye Parazitoloji Derneği - Makale metnine www.tparazitolderg.org web sayfasından ulaşılabilir. 


\section{INTRODUCTION}

Vitamin $A$ is one of the most important fat-soluble vitamins and found in green plants as carotenoid precursors. It is needed for normal growth and development, good reproduction parameters and maintenance of skeletal and epithelial tissue. $\beta$-carotene, the main precursor of vitamin $A$, is one of the most widely available carotenoids. Abortions, increased prevalence of retained fetal membranes, and increased calf morbidity and mortality are indicators of vitamin A deficiency in gestating cows. Vitamin A deficiency often results in increased prevalence of infectious diseases, because $\beta$-carotene, independent of its provitamin A function, is an antioxidant and can enhance the $T$ and $B$ cell function and killing ability of neutrophils (1-3). In young animals, vitamin A deficiency results in poor growth and weight gain, ataxia, convulsions, night blindness and total blindness. Secondary deficiency can arise where there is sufficient vitamin $A$ /carotene in the diet but it does not reach a normal tissue level due to a failure in digestion, absorption or metabolism (4). Secondary vitamin A deficiency may occur in cases of chronic disease of the liver or intestines because of their contribution on conversion of carotene to vitamin A (5). In metabolism, the liver plays a crucial role in vitamin A physiology as retinoid is mainly metabolized and stored in the liver. There are two hepatic cell types important to these processes, including the parenchymal cells (hepatocytes) and the hepatic stellate cells (HSCs). It is well known that hepatocytes are involved centrally in the uptake and processing of retinol in the liver, and that HSCs play a central role in hepatic retinoid storage $(6,7)$.

Hepatitis may be associated with a number of agents, such as liver parasite. Hydatid cysts, which develop in the lungs and/or liver of sheep and cattle, are also acquired from tapeworm eggs excreted by infected carnivores. In parasitic hepatitis the changes depend upon the number and type of migrating parasites. In massive fluke infestations sufficient damage may occur to cause acute or chronic hepatic insufficiency. Fasciola hepatica is the most common and important liver fluke that may infest all domestic animals. It has major economic importance in the sheep or cattle industry (8). Migration of young flukes is large enough to do substantial mechanical damage to liver parenchyma. Then induced lesions begin to heal via ingrowth of granulation tissue, leading to scarring lesions that could lead to extensive liver insufficiency (9). Fluke's infection may limit growth rates and feed conversion in growing heifers and growth rate in beef cattle. Decreased milk yields reduced butter fat and increased calving interval and are considered adverse effects of fluke infection on production in dairy cattle (10-12).

Many investigations have reported the relation between the carotenoid and vitamin A content of the serum and blood of cattle under different dietary and pathological conditions (3, 13-16). According to our surveys, there is not documented study on the association of parasite induced hepatic lesions and serum vita$\min A$ and $\beta$-carotene status in cattle. Therefore, the objective of the present study was to determine the relationship between the most prevalent liver damages and serum vitamin $A$ and $\beta$-carotene levels in adult cattle.

\section{METHODS}

Two hundred Holstein (mixed-breed) cattle, aged 4-5 years, slaughtered in Urmia slaughterhouse in East Azerbaijan province from July to August 2011 were used in the present study. A total number of 150 samples ( $F$. hepatica $=50, D$. dendriticum $=50$ and hydatid cyst $=50$ ) were selected according the type of liver parasitic infections after postmortem examinations and confirmation. Fifty samples were obtained from cattle without any parasitic infection in the liver as a control group.

Blood samples were collected from the jugular vein into evacuated 10 mlLtube and kept at room temperature for $2 \mathrm{~h}$ in order to obtain the serum. The serum taken into the centrifuge tubes was centrifuged at $3.000 \mathrm{rpm}$ for $15 \mathrm{~min}$ and within $24 \mathrm{~h}$ was stored into the serum preservation tubes at $-20^{\circ} \mathrm{C}$ until the analysis was performed. The plasma $\beta$-carotene and vitamin A levels were analyzed according to a method described by Suzuki and Katoh (17). Briefly, one $\mathrm{mL}$ of each serum sample was mixed with 1.0 $\mathrm{mL}$ of $96.5 \%$ ethanol in a test tube, followed by $3.5 \mathrm{~mL} 98.5 \%$ hexane. Tubes were shaken for $10 \mathrm{~min}$ and centrifuged at $800 \times$ $\mathrm{g}$ for $10 \mathrm{~min}$. Spectrophotometric absorbance of supernatants was measured at $453 \mathrm{~nm}$ and $325 \mathrm{~nm}$ for $\beta$-carotene and vitamin $A$, respectively. $\beta$-carotene and vitamin A concentrations $(\mu \mathrm{g} / \mathrm{dL})$ were calculated by related equations (17).

Serum samples were assayed for alanine aminotransferase (ALT) and aspartate aminotransferase (AST) activity using commercial diagnostic kits (Zist-Shimi, Tehran, Iran). Then the severity of the hepatic involvement was classified according to the enzyme activity to mild, moderate and severe involvement as follow:

Severe form: AST>200 and ALT>80 (U/L)

Moderate form: AST 150-200 and ALT60-80 (U/L)

Mild form: $A S T<150$ and $A L T<60(U / L)$

\section{Statistical analysis}

The data obtained in the present study were expressed as mean \pm SEM. In respect of statistical calculations, data were subjected to analysis of variance (ANOVA). The statistical significance of the relevant factors was analyzed by the Tukey's HSD (Honest Significant Difference) test. Relationships between the parameters of the variables in the cattle were calculated by linear regression and Pearson correlation test, including the correlation coefficient and significance of the correlation. A value of $p<0.05$ was considered statistically significant. All analyses were carried out using a statistical analysis system with software Statistical Packages for the Social Sciences (SPSS) version 19 (IBM Corp.; Armonk, NY, USA).

\section{RESULTS}

\section{Parasitic infection and serum Vit. A level}

The mean concentrations of serum vitamin $A$ and $\beta$-carotene values in all groups were given in Table 1. All forms of three different natural parasitic infections in the cattle livers led to significantly $(p<0.05)$ decline in the serum vitamin A level. Only in the mild form of $D$. dendriticum infection, vitamin A level was not significantly lower $(p>0.05)$ than that of the control group. More pronounced and significant $(p<0.01)$ diminish in serum vitamin $A$ level $(13.33 \pm 0.158)$ was seen in cattle with severe form of hydatid cyst infection. Compared to parasitic infected groups and the 
Table 1. Comparison of the selected parameters of serum between the four groups of cattle $(m e a n \pm S E M)$

\begin{tabular}{|c|c|c|c|c|c|}
\hline Animal group & Severity of Involvement & Vit. A & $\beta$-Carotene & AST (units/L) & ALT (units/L) \\
\hline \multirow{3}{*}{ Fasciola hepatica } & Mild (15) & $24.99 \pm 0.41$ & $23.08 \pm 0.42$ & $134.20 \pm 2.38$ & $46.21 \pm 2.22$ \\
\hline & Moderate (18) & $21.94 \pm 0.14$ & $20.15 \pm 0.19$ & $176.10 \pm 2.77$ & $68.57 \pm 1.29$ \\
\hline & Severe (17) & $18.68 \pm 0.17$ & $20.27 \pm 0.21$ & $237.45 \pm 6.43$ & $127.33 \pm 4.40$ \\
\hline \multirow[t]{3}{*}{ Dicrocoelium dendriticum } & Mild (15) & $28.06 \pm 0.35$ & $26.48 \pm 0.70$ & $136.31 \pm 3.98$ & $37.84 \pm 0.99$ \\
\hline & Moderate (19) & $25.18 \pm 0.16$ & $22.78 \pm 0.18$ & $175.83 \pm 3.14$ & $72.00 \pm 1.67$ \\
\hline & Severe (16) & $22.42 \pm 0.16$ & $20.53 \pm 0.24$ & $244.08 \pm 4.67$ & $119.10 \pm 4.81$ \\
\hline \multirow[t]{3}{*}{ Echinococcus granulosus } & Mild (18) & $20.70 \pm 0.25$ & $21.10 \pm 0.26$ & $137.45 \pm 1.78$ & $49.70 \pm 1.95$ \\
\hline & Moderate (18) & $16.73 \pm 0.29$ & $20.96 \pm 0.34$ & $171.80 \pm 2.14$ & $72.47 \pm 1.06$ \\
\hline & Severe (14) & $13.32 \pm 0.15$ & $19.27 \pm 0.31$ & $253.5 \pm 19.30$ & $188.1 \pm 13.50$ \\
\hline \multicolumn{2}{|l|}{ Normal cattle ${ }^{\mathrm{b}}(50)$} & $29.76 \pm 0.28$ & $27.52 \pm 0.25$ & $88.26 \pm 3.47$ & $32.67 \pm 0.71$ \\
\hline \multicolumn{6}{|c|}{$\begin{array}{l}\text { "Number in parenthesis indicates the number of animals in the subgroups } \\
\text { bAnimals without any apparent parasitic infection in liver } \\
\text { ALT: Alanine aminotransferase; AST: Aspartate aminotransferase } \\
\star \text { `Significant differences }(p<0.05) \text { were detected in parameters level in comparison with normal cattle }\end{array}$} \\
\hline
\end{tabular}

Table 2. Regression analysis of the relationship between the concentrations of serum Vit. A and $\beta$-carotene levels and selected liver enzyme activity in cattle with various forms of Dicrocoelium dendriticum infection

\begin{tabular}{|c|c|c|c|c|c|c|c|c|c|}
\hline & \multicolumn{3}{|c|}{ Mild form } & \multicolumn{3}{|c|}{ Moderate form } & \multicolumn{3}{|c|}{ Severe form } \\
\hline Parameter & Vit.A & $\beta$-carotene & ALT & Vit.A & $\beta$-carotene & ALT & Vit.A & $\beta$-carotene & ALT \\
\hline$\beta$-carotene & 0.82 & - & - & 0.52 & - & - & 0.25 & - & - \\
\hline$A L T$ & 0.12 & -0.47 & - & 0.20 & 0.05 & - & 0.15 & 0.06 & - \\
\hline AST & -0.88 & -0.99 & 0.36 & 0.08 & -0.14 & 0.27 & 0.12 & -0.08 & -0.11 \\
\hline
\end{tabular}

control, D. dendriticum infection in the liver caused a lesser and non-significant $(p<0.05)$ decrease in serum vitamin A level.

\section{Parasitic infection and serum $\beta$-carotene level}

Except for the mild form of $D$. dendriticum infection, the serum $\beta$-carotene levels were significantly $(p<0.05)$ decreased in all groups. Similar process was detected in serum vitamin A level. Interestingly, the serum $\beta$-carotene levels in all the infective groups were almost in same level or in narrow range differences whereas the vitamin A levels showed very wide-ranging differences.

\section{Parasitic infection and serum AST and ALT levels}

The comparison of serum AST levels between the mild form of three parasitic groups (Table 1) indicated that there were no significant differences in AST activity between cattle with various forms of infections while significant differences were seen in cattle without apparent parasitic infection as the control group $(p<0.01)$. In all animals suffering from parasitic diseases, the serum activity of ALT was statistically higher than in cattle without apparent parasitic infection $(p<0.01)$ (Table 1).

\section{Relationship between serum vitamin $A$ and $\beta$-carotene concentrations}

Serum $\beta$-carotene and vitamin A concentrations (mean \pm S.E.M) at healthy group ranged from 23.65 to $33.65 \mu \mathrm{g} / \mathrm{dL}(27.52 \pm 0.25)$ and from 29.48 to $37.84(29.76 \pm 0.28) \mu \mathrm{g} / \mathrm{dL}$, respectively.
Serum $\beta$-carotene at normal group of cattle was positively correlated $(r=0.87 ; p<0.001)$ with serum vitamin $A$; however, there was no significant correlation between other measured parameters.

The relationship between serum vitamin $A$ and $\beta$-carotene of cattle in all forms of parasitic infection of the liver with $D$. dendriticum were not significant owing to the low concentrations in this condition (Table 2). Correlation among the serum vitamin A and AST activity of liver at dicrocoeliosis was negative and non-significant ( $p>0.05)$.

Table. 3 showed the relationship between vitamin A, $\beta$-carotene and liver enzyme concentrations in 50 serum samples from cattle with $F$. hepatica infection. The Spearman correlation between serum $\beta$-carotene concentrations and serum vitamin A concentrations in mild and moderate form of fasciolosis was $r=0.78$ and $r=0.53$, respectively $(p<0.0001)$. The correlation between vitamin $A$ and $\beta$-carotene concentration was $r=0.39$ ( $p>0.05)$ among 17 cases of severe fasciolosis.

Except for mild involvement with hydatid cyst infection, assessment of the correlations between the evaluated variables in cattle (Table 4) showed a non-significant and negative correlation between the concentrations of serum vitamin A ( $p>0.05)$, $\beta$-carotene $(p>0.05)$ and ALT ( $p>0.05)$ activities. 
Table 3. Regression analysis of the relationship between the concentrations of serum Vit.A and $\beta$-carotene levels and selected liver enzyme activity in cattle with various forms of Fasciola hepatica infection

\begin{tabular}{|l|c|c|c|c|c|c|c|c|c|}
\hline & \multicolumn{3}{|c|}{ Mild form } & \multicolumn{3}{c|}{ Moderate form } & \multicolumn{3}{c|}{ Severe form } \\
\hline Parameter & Vit.A & $\beta$-carotene & ALT & Vit.A & $\beta$-carotene & ALT & Vit.A & $\beta$-carotene & ALT \\
\hline$\beta$-carotene & $0.78^{\star}$ & - & - & $0.53^{\star}$ & - & - & 0.39 & - & - \\
\hline ALT & 0.07 & 0.21 & - & 0.00 & 0.16 & - & 0.45 & -0.07 & - \\
\hline AST & -0.4 & -0.50 & 0.02 & 0.09 & -0.09 & 0.17 & 0.10 & 0.13 & -0.11 \\
\hline $\begin{array}{l}\text { ALT: alanine aminotransferase; AST: aspartate aminotransferase } \\
\text { Correlation coefficient values (R) were presented } \\
*: \text { significance of the correlation p }<0.05\end{array}$
\end{tabular}

Table 4. Regression analysis of the relationship between the concentrations of serum Vit. A and $\beta$-carotene levels and selected liver enzyme activity in cattle with various forms of hydatid cyst infection

\begin{tabular}{|c|c|c|c|c|c|c|c|c|c|}
\hline & \multicolumn{3}{|c|}{ Mild form } & \multicolumn{3}{|c|}{ Moderate form } & \multicolumn{3}{|c|}{ Severe form } \\
\hline Parameter & Vit.A & $\beta$-carotene & ALT & Vit. A & $\beta$-carotene & ALT & Vit.A & $\beta$-carotene & ALT \\
\hline$\beta$-carotene & 0.16 & - & - & -0.10 & - & - & -0.13 & - & - \\
\hline ALT & -0.04 & -0.34 & - & -0.11 & -0.08 & - & -0.13 & -0.17 & - \\
\hline AST & 0.13 & -0.15 & $0.51^{*}$ & 0.06 & -0.16 & $0.78^{*}$ & -0.37 & 0.54 & 0.22 \\
\hline
\end{tabular}

In the other method of the correlations assessment between the evaluated variables, we evaluated all cases $(N=50)$ with various forms of infections in a single group. The concentrations of the serum $\beta$-carotene were positively correlated with corresponding concentrations of vitamin $A(p<0.001)$ in all groups. Statistical results showed a significant negative correlation between the concentrations of $\beta$-carotene and vitamin $A(p<0.001)$ enzyme activities of the liver $(p<0.001)$ in all three types of liver infections. On the other hand, the concentrations of $\beta$-carotene and vitamin $A$ in cattle after liver involvement were significantly negatively correlated with the values of liver enzymes $(p<0.001)$.

\section{DISCUSSION}

Vitamin A, or several forms of carotene as provitamin A, are found in plants, but carotene is not biologically active (18). Secondary deficiency of vitamin A can arise where there is sufficient vitamin $\mathrm{A}$ /carotene in the diet, however it does not get to a normal tissue level due to failure in digestion, absorption, or metabolism.

Hepatic stellate cells (HSCs) are called vitamin A-storing cells and support the sinusoidal endothelium. Different aspects of liver homeostasis, including vitamin A storage, matrix remodeling and local inflammation organized with HSCs, have been discussed previously (19). The great part of total vitamin A storage $(50 \%-80 \%)$ in the whole body is reserved in the cytoplasm of these cells. HSCs also regulate both transport and storage of vitamin A (20).

Liver fibrosis is a pathological reaction to chronic hepatic damage induced by different etiologies, including infectious agents and a number of poisons (20). The HSCs which store vitamin A located in the liver sinusoid play an important role in fibrosis development, and it is proposed that cytokines produced in the peri-parasitic area could be involved in collagen production $(21,22)$.
F. hepatica and $D$. dendriticum are common trematodes with world-wide distribution that are observed principally in ruminants, causing important economic losses due to liver condemnation (23). In parasitic hepatitis, the number and type of migrating parasites determine nature of changes. In massive fluke infestations, sufficient damage may occur to cause acute and chronic hepatic insufficiency. Apart from the mechanical irritation caused by the migrant flukes, pathologic changes have been described to the toxic effects of metabolic products released by the parasite (9). Thus, determination of serum levels of hepatic enzymes usually is used for evaluation of hepatic disorders (5). In the present study the liver infection was confirmed in gross examination in slaughterhouse. Moreover, increased serum ALT and AST activities have been correlated with active liver cell necrosis and as mentioned above the hepatocyte destruction is a central aspect of most forms of fibrotic liver injuries (24).

Oka et al. (25) reported a strong relationship between serum and liver vitamin A concentrations in cattle. Vitamin A levels in the plasma are used extensively in diagnostic and experimental work. Normal serum vitamin A concentrations in cattle range from 25 to $60 \mu \mathrm{g} / \mathrm{dL}$. The clinical signs may correlate with the serum concentrations of vitamin A. Plasma levels of $20 \mu \mathrm{g} / \mathrm{dL}$ are the minimal concentration for vitamin A adequacy (5). In the present study vitamin A levels range were $26.48-37.48 \mu \mathrm{g} / \mathrm{dL}$ in normal healthy cattle. Naturally infected cattle with $D$. dendriticumi, F. hepatica and cyst hydatid showed lesser amount of vitamin A levels as follow (21.14-28.64 $\mu \mathrm{g} / \mathrm{dL}),(17.41-26.95 \mu \mathrm{g} / \mathrm{dL})$ and (12.64-22.84 $\mu \mathrm{g} / \mathrm{dL}$ ), respectively. Accordingly, Vitamin A level in healthy cattle was in normal status where naturally infected cattle represented low level than normal range. Serum vitamin A level in animals suffering from $D$. dendriticum involvement did not reveal marked decrease, although animals infected with cyst 
hydatid displayed more prominent drop in serum vitamin A concentrations.

Otranto and Travcrsa (23) demonstrated that dicrocoeliosis pathogenicity is low because $D$. dendriticum does not migrate across the liver parenchyma. Therefore, this type of parasitic infection may have lesser effect on HSCs that are involved in loading of vitamin $A$ and $\beta$-carotene in liver and their serum levels. According to the results of the present study, vitamin $A$ and $\beta$-carotene concentrations were marginally affected by this type of infection.

Plasma carotene levels vary largely affected by the diet. In cattle, levels of $150 \mu \mathrm{g} / \mathrm{dL}$ are optimum and in the absence of supplementary vitamin $A$ in the ration clinical signs appear when the levels fall to $9 \mu \mathrm{L} / \mathrm{dL}$ (5). In the present study, healthy cattle nearly showed normal values, however, a significant drop of carotene levels presented in various forms of liver infections and reached its lowest level (minimum level) in hydatid cyst involvement. Our results showed that the level of serum $\beta$-carotene in naturally infected groups was significantly lower compared to the healthy group.

The relationship of serum $\beta$-carotene concentrations to vitamin A concentrations did not show differences by dicrocoeliosis and fasciolosis status of the cattle, however, in moderate and severe cyst hydatid there was a negative correlation among these factors.

Parasitic liver infection lead to lower levels of vitamin A and its metabolite in the present study. A number of studies have reported that the liver vitamin $A$ is decreased under various pathological conditions $(14,26)$. Progressive liver disease results in the pronounced depletion of hepatic retinoid and vitamin A content in human (26). An association between SSC and the concentrations of vitamin $A$ and $\beta$-carotene in plasma is reported (16). $\beta$-carotene also acts independent from vitamin $A$ in mastitis and reproduction, and it has no association with fertility disorders and first Al (15). Based on California Mastitis Test, low concentrations of plasma vitamin $A$ and $\beta$-carotene are associated with severity of mastitis (3). Other researchers showed that supplemental vitamin A plus $\beta$-carotene before drying-off lead to fewer new infections during the early dry period than other cows (16). Animals suffering from vitamin A deficiency, both the frequency and severity of bacterial, viral and protozoal infections, are increased $(13,27)$. Glucocorticoid concentrations are elevated in vitamin A-deficient sheep cause to decrease in serum Ig levels and other immune functions $(13,27)$. Accordingly one of our hypotheses is that low levels of vitamin $A$ and $\beta$-carotene may be contributed in parasitic infections in the liver.

The carotenoids stored in HSCs lipid droplets play a protective role and are involved in scavenging reactive oxygen species against hepatic insults. It has already been demonstrated that liver detoxification systems and antioxidant defense capabilities have been extensively involved in the trematode induced liver injuries, such as fasciolosis and dicroceliosis (24). Then, in absence of these stores, an injury to the liver will result in fibrosis and hepatic disease $(28,29)$. It seems that lower levels of $\beta$-carotene could enhance hepatic cells damage when there are pathologic conditions in the liver, as observed in the present study.
There is a strong relationship between serum and liver vitamin A concentrations in cattle (25). However, more definitive studies need to be conducted before the linkage between the loss of HSC retinoid stores and hepatic disease can be determined in domestic animal. In addition, it could be suggested that in cattle infested with parasitic hepatitis, the vitamin A storage in liver and extra-hepatic tissue and mobilization from the liver to other organs after chronic infectious hepatitis need to be considered in further investigations.

Consequently, apart from conditions that may warrant additional supplementation of vitamin A, including diets with lower green food or lower quality forages and increased demand in systemic pathologic conditions, the increased exposure of animals to liver parasitic pathogens and reduced antioxidant potential should be taken into consideration.

\section{CONCLUSION}

The levels of serum vitamin $A$ and $\beta$-carotene were lower in naturally infected cattle as compared to the control cattle without any apparent liver parasite infection. It should be noted that hydatid cyst involvement produced markedly lower carotenoid levels. Vitamin supplements should be supplied to animals with parasitic hepatitis to support their growth and production performances and increase their resistance to diseases. It remains unclear whether influence of parasitic hepatitis on low levels of vitamin A and $\beta$-carotene or liver parasitic damage could lead to decline in vitamin $A$ and $\beta$-carotene levels.

Ethics Committee Approval: Ethic committee approval was received for this study from the ethic committee of Urmia University (2011-267).

Informed Consent: Not required in this study

Peer-review: Externally peer-reviewed.

Author Contributions: Concept - B.E.; Design - B.E.; Supervision - B.E.; Data Collection and/or Processing - F.F.; Analysis and/or Interpretation - B.E., J.G.; Literature Review - B.E.; Writing - B.E.; Critical Review - J.G.; Other - J.G.

Conflict of Interest: No conflict of interest was declared by the authors.

Financial Disclosure: The authors declared that his study has received no financial support.

Etik Komite Onayı: Bu çalışma için Etik komite onayı Urmia Üniversitesi Etik Kurulu'ndan alınmıştır (2011-267)

Hasta Onamı: Bu çalışma için hasta onamına gerek yoktur.

Hakem Değerlendirmesi: Dış bağımsız.

Yazar Katkıları: Fikir - B.E.; Tasarım - B.E.; Denetleme - B.E.; Veri Toplanması ve/veya Isşlemesi - F.F.; Analiz ve/veya Yorum - B.E., J.G.; Literatür Taraması - B.E.; Yazıyı Yazan - B.E.; Eleştirel İnceleme - J.G.; Diğer - J.G.

Çıkar Çatışması: Yazarlar çıkar çatışması bildirmemiştir.

Finansal Destek: Yazarlar bu çalışma için finansal destek almadıklarını beyan etmişlerdir.

\section{REFERENCES}

1. Paik J, During A, Harrison EH, Mendelsohn CL, Lai K, Blaner WS. Expression and characterization of a murine enzyme able to cleave beta-carotene. The formation of retinoids. J Biol Chemis 2001; 276: 32160-8. [CrossRef] 
2. Cantorna MT, Nashold FE, Hayes CE. In Vitamin A deficiency multiple mechanisms establish a regulatory $T$ helper cell imbalance with excess Th1 and insufficient Th2 function. J Immunol 1994; 152: 151522.

3. Chew BP, Hollen LL, Hillers JK, Herlugson ML. Relationship between vitamin $A$ and $\beta$-carotene in blood plasma and milk and mastitis in Holsteins. J Dairy Sci 1982; 65: 2111-8. [CrossRef]

4. Andrews A.H. Other Calf Problems. In: Andrews AH, Blowey RW, Boyd H, Eddy RG, editors. Bovine Medicine Diseases and Husbandry of Cattle. Second edition. Blackwell Science Ltd. Blackwell Publishing Company; 2004. P. 249-63.

5. Radostits OM, Gay CC, Hinchcliff KW, Constable PD, Done SH, Jacobs DE, et al. Veterinary Medicine, A Textbook of the Diseases of Cattle, Horses, Sheep, Pigs, and Goats. 10rd ed. Elsevier Saunders; 2007.

6. Blaner WS, O'Byrne SM, Wongsiriroj N, Kluwe J, D'Ambrosio DM, Jiang $\mathrm{H}$, et al. Hepatic stellate cell lipid droplets: A specialized lipid droplet for retinoid storage. Biochim Biophys Acta 2009; 1791: 46773. [CrossRef]

7. Friedman SL. Hepatic stellate cells: protean, multifunctional, and enigmatic cells of the liver. Physiol Rev 2008; 88: 125-72. [CrossRef]

8. Howell A, Baylis M, Smith R, Pinchbeck G, Williams D. Epidemiology and impact of Fasciola hepatica exposure in high-yielding dairy herds. Prev Vet Med 2015; 121: 41-8. [CrossRef]

9. Jones T, Hunt R, King N. Veterinary Pathology.6rd ed. Lippincott Williams and Wilkins; 1997.

10. Schweizer G, Braun U, Deplazes P, Torgerson PR. Estimating the financial losses due to bovine fasciolosis in Switzerland. Vet Rec 2005; 157: 188-93. [CrossRef]

11. Charlier J, Duchateau L, Claerebout E, Williams D, Vercruysse J. Associations between anti-fasciola hepatica antibody levels in bulktank milk samples and production parameters in dairy herds. Prev Vet Med 2007; 78: 57-66. [CrossRef]

12. Khan MK, Sajid MS, Khan MN, Iqbal Z, lqbal MU. Bovine fasciolosis: prevalence, effects of treatment on productivity and cost benefit analysis in five districts of Punjab, Pakistan. Res in Vet Sci 2009; 87: 70-5. [CrossRef]

13. Webb KE Jr, Mitchell GE Jr, Little CO, Schmitt GH. Polyuria in vitamin A-deficient sheep. J Anim Sci 1968; 27: 1657-62. [CrossRef]

14. Braun W. Studies on the Carotenoid and Vitamin A Levels in Cattle. I. Seasonal Changes of the Carotenoid and Vitamin A Levels and the Normal Carotenoid-Vitamin A Ratio of the Blood. J Nutrition. 1945; 29: 61-71.

15. Jukola E, Hakkarainen J, Saloniemi H, Sanakari S. Blood selenium, vitamin $E$, vitamin $A$, and $\beta$-carotene concentrations and udder health, fertility treatments and fertility. J Dair Sci 1996; 79: 838-45. [CrossRef]

16. O'Rourke D. Nutrition and udder health in dairy cows: a review. Irish Vet J 2009; 62: 15-20. [CrossRef]

17. Suzuki J, Katoh N. A simple and cheap method for measuring serum vitamin $A$ in cattle using only a spectrophotometer. Japan J Vet Sci 1990; 52: 1281-3. [CrossRef]

18. Blomhoff R, Green MH, Green JB, Berg T, Norum KR. Vitamin A metabolism: new perspectives on absorption, transport and storage. Physiol Rev 1991; 71: 951-90. [CrossRef]

19. Tsukamoto H, Lu SC. Current concepts in the pathogenesis of alcoholic liver injury. FASEB J 2001; 15: 1335-49. [CrossRef]

20. Senoo H, Imai K, Mezaki Y, Miura M, Morii M, Fujiwara M, et al. Accumulation of Vitamin A inthe Hepatic Stellate Cell of Arctic Top Predators. Anat Rec (Hoboken) 2012; 295: 1660-8. [CrossRef]

21. Grenard P, Bresson-Hadni S, El Alaoui S, Chevallier M, Vuitton DA, Richard-Blum S. Transglutaminase-mediated cross-linking is involved in the stabilization of extracellular matrix in human liver fibrosis. J Hepatol 2001; 35: 367-75. [CrossRef]

22. Guerret S, Vuitton DA, Liance M, Pater C, Carbillet JP. Echinococcus multilocularis: relationship between susceptibility/resistance and liver fibrogenesis in experimental mice. Parasitol Res 1998; 84: 657-67. [CrossRef]

23. Otranto D, Travcrsa D. Dicrocoeliosis of ruminants: a little known fluke disease. Trend Parasitol 2003; 19: 12-5. [CrossRef]

24. Sánchez-Campos S, González P, Ferreras C, García-Iglesia MJ, González-Gallego J, Tuñón MJ. Morphologic and Biochemical Changes Caused by Experimentally Induced Dicroceliosis in Hamsters (Mesocricetus auratus). Com Med 2000; 50: 147-52.

25. Oka A, Maruo Y, Miki T, Yamasaki T, Saito T. Influence of vitamin A on the quality of beef from the Tajima strain of Japanese Black cattle. Meat Sci 1998; 48: 159-67. [CrossRef]

26. Ralli EP, Papper E, Paley K, Bauman KP. Vitamin A and carotene content of human liver in normals and diseased subjects. Archiv Inter Med 1941; 68: 102-11. [CrossRef]

27. Bruns NJ, Webb KE J. Vitamin A deficiency: serum cortisol and humoral immunity in lambs. J Anim Sci 1990; 68: 454-9. [CrossRef]

28. Yamaguchi K, Yang L, McCall S, Huang J, Yu XX, Pandey SK, et al. Diacylglycerol acyltransferase 1 anti-sense oligonucleotides reduce hepatic fibrosis in mice with nonalcoholic steatohepatitis. Hepatol 2008; 47: 625-35. [CrossRef]

29. Kankofer M, Albera E. Postpartum relationship of beta carotene and vitamin A between placenta, blood and colostrum in cows and their newborns. Exp Clin Endocrinol Diabet 2008; 116: 409-12. [CrossRef] 